\title{
A rhetorical approach to the genre of the abstract within the field of Food Science and Technology
}

\author{
MARía Milagros del SAZ-RUBio \\ Escuela Técnica Superior de Ingeniería Agronómica y del Medio Natural \\ Departamento de Lingüística Aplicada \\ Universitat Politècnica de València \\ Camino de Vera, s/n \\ 46022 Valencia \\ E-mail: masaru@idm.upv.es
}

\section{A RHETORICAL APPROACH TO THE GENRE OF THE ABSTRACT WITHIN THE FIELD OF FOOD SCI- ENCE AND TECHNOLOGY}

\begin{abstract}
In this paper I have outlined the rhetorical structure of 50 abstracts from the field of Food Science and Technology and have assessed how metadiscoursal features are used across its different moves. 25 abstracts were authored by researchers with English as their $\mathrm{L} 1$, and the other 25 were written by Spanish researchers. In general terms, $54 \%$ of the abstracts deploy the moves traditionally associated with the IRMD and CARS structure, whereas $46 \%$ of the abstracts exclusively follow the IMRD structure and, hence, do not use topic contextualization or gap signalling. English researchers tend to write more complex abstracts with regard to move and steps deployment. Interpersonal features occur with a normalized frequency of 29.2 per 1000 words, especially in moves 5 (56\% of the features), $1(16 \%), 6(14 \%)$ and $3(10 \%)$. English researchers tend to use metadiscoursal features with a slightly higher frequency $(59 \%)$ than the Spanish group $(41 \%)$.
\end{abstract}

KEY WORDS: abstract; rhetorical structure; Food Science and Technology; metadiscourse.

SUMMARY: 1 . Introduction. 2. Review of the literatura. 3. Corpus of analysis. 4. Results and discussion. 5. Concluding remarks.
UNA APROXIMACIÓN RETÓRICA AL GÉNERO DEL RESUMEN DENTRO DE LA DISCIPLINA DE LA CIENCIA Y TECNOLOGÍA DE ALIMENTOS

RESUMEN: En este trabajo se analiza la estructura retórica de 50 resúmenes pertenecientes a la disciplina de la Ciencia y Tecnología de los Alimentos y se cuantifica la presencia de elementos metadiscursivos en los diferentes movimientos que los integran. 25 de los resúmenes fueron escritos por investigadores con inglés como lengua materna y otros 25 por investigadores españoles. En términos generales, un $54 \%$ de los resúmenes incorpora los movimientos típicos de las estructuras IMRD y CARS, mientras que un $46 \%$ de los mismos participan solamente de la estructura IMRD sin hacer referencia a la contextualización del tema o la mención del nicho o problema existente. Los investigadores nativos del inglés tienden a escribir resúmenes retóricamente más complejos. En lo que respecta al uso de elementos metadiscursivos, la frecuencia normalizada es de 29,2 por cada 1.000 palabras. Los escritores nativos del inglés recurren a su uso con una frecuencia ligeramente superior a los españoles $(59 \%$ frente a $41 \%)$.

PALABRAS ClAVES: resumen; estructura retórica; Ciencia y Tecnología de Alimentos; elementos metadiscursivos.

SUMARIO: 1 . Introducción. 2. Revisión de la literatura. 3. Corpus de análisis. 4. Resultados y discusión. 5. Conclusiones.
UNE APPROCHE RHETORIQUE AU GENRE DU RESUME DANS LE DOMAINE DES SCIENCES ET TECHNOLOGIE DES ALIMENTS

RÉSUMÉ: Cet article analyse la structure rhétorique de 50 résumés appartenant à la discipline des sciences et technologie des aliments et quantifie la présence d'éléments métadiscursifs dans les différents mouvements qui les composent. 25 résumés ont été rédigés par des chercheurs ayant l'anglais comme langue maternelle et 25 autres par des chercheurs espagnols. D'une manière générale, $54 \%$ des résumés intègre les mouvements typiques des structures IMRD et CARS, alors que les $46 \%$ restant n'incorporent que la structure IMRD sans référence à la contextualisation du sujet ou au problème existant. Les chercheurs anglophones autochtones ont tendance à écrire des résumés rhétoriquement plus complexes. En ce qui concerne l'utilisation d'éléments métadiscursifs, la fréquence normalisée est de 29,2 pour 1000 mots. Les écrivains anglais natifs ont recours à leur utilisation avec une fréquence légèrement supérieure à celle des Espagnols (59\% contre 41\%).

MOTS CLÉS: résumé; structure rhétorique; sciences et technologie des aliments; éléments métadiscursifs.

SOMMAIRE: 1. Introduction. 2. Cadre théorique. 3. Corpus d'analyse. 4. Résultats et discussion. 5. Conclusion.
Fecha de Recepción Fecha de Revisión Fecha de Aceptación Fecha de Publicación 


\title{
A rhetorical approach to the genre of the abstract within the field of Food Science and Technology
}

\author{
María Milagros DEl SAZ-RUBio
}

\section{INTRODUCTION}

Nowadays, mastering the writing of an abstract is a must for researchers and academics who want to achieve promotion and visibility in the academic discourse community to which they belong. In this respect, already established researchers and, in particular, novice ones, do not only have to be familiar with the global structure of the abstract and its organizational patterning or rhetorical structure, but they also need to attain some knowledge of the conventional linguistic realizations that are most commonly enacted to realize such rhetorical functions, i.e., the use of metadiscoursal units, such as hedges, boosters, reporting verbs, or authorial stance. In this line, a growing body of literature on the research article (RA) abstract started almost two decades ago with studies focusing on the rhetorical structure of abstracts from a specific discipline, for example, Salager-Meyer (1990) and Anderson and Maclean (1997) on the rhetorical structure of medical English abstracts, Kaplan et al. (1994) on applied linguistics, Santos (1996) on applied linguistics abstracts, Huckin (2001) on biomedical abstracts, Hartley (2003) on psychology abstracts, Samraj (2002) on biology, Martin- Martín (2002) on Spanish and English experimental social sciences abstracts, Lorés (2004) on linguistics abstracts, and San and Tan (2012) on computer science. On top of this, research across disciplines and/or languages has also been prolific with the work of Hyland, (2000) and the research by Melander et al. (1997) on abstracts produced by American and Swedish non-native speakers in linguistics, biology and medicine, or Pho's (2008) research on educational and applied linguistic abstracts, together with the work of Kafes (2012) on abstracts in the social sciences written by American, Taiwanese and Turkish scholars, Doró (2013) on the rhetorical structure of linguistics and literature abstracts, and Tankó's (2017) paper on literary research articles and their rhetorical moves and linguistic realizations. In the same vein, other studies have focused on the use of certain linguistic and/or metadiscoursal features. Thus, Salager-Meyer (1992) analysed modality and verb tense distribution across moves, Pho focused (2008) on the distribution of verb tenses and stance across applied linguistics and educational technology abstracts, Gillaerts and Van de Velde (2010) dealt with interpersonality in a diachronic study, Busà's study (2005) was on metadiscourse in economics and psychology abstracts, or Hu and Cao's (2011) research on hedges and boosters in Chinese and English abstracts. Likewise, Bellés and Querol (2010) carried out a contrastive analysis of evaluative language in a corpus of English and Spanish medical abstracts. 
What all these studies have come to show is that, in spite of the traditional view that abstracts are merely expository or informative objective presentations, as stated in the guidelines provided by the American National Standards for Writing Abstracts (1979), as well as by guidelines or books on academic writing, abstracts are more than mere synopsis of a research paper (Bhatia 1993). Thus, the status of the research abstract as a separate genre and its promotional value is now commonly accepted. Not in vain, as Hyland has stated (2000), abstracts have the key function of helping readers decide on whether to keep reading or discarding the whole research paper. This is of special relevance in electronic abstracting journal databases since the abstract constitutes, most of the time, the only chance that researchers have to lure their potential readers into giving the papers their full attention. Thus, the research by Hunston (1993) and Stotesbury (2003) has shown that abstracts are evaluative and persuasive entities where researchers present their own personal judgements by means of attitudinal lexis together with hedging and boosters to express their degree of commitment or their certainty regarding the proposition conveyed.

Bearing all this in mind, the aim of this paper is to present a template of the rhetorical organization of abstracts in the uncharted field of Food Science and Technology by using move and step analysis. A secondary, and equally important aim, is to unveil the conventional linguistic and metadiscoursal realizations that writers use in order to achieve such rhetorical functions. In this respect, this piece of research aims to add to previous studies on disciplinary variation, considering that, as Swales points out (1990:4), writing should be viewed as the process an individual undergoes in "response to the discourse conventions which arise from preferred ways of creating and communicating knowledge within particular communities". On top of this, it is also my aim to account for any similarity and/or differences between the rhetorical choices made by English and Spanish-background writers of these RA abstracts.

\section{REVIEW OF THE LITERATURE}

In the following sections I will briefly comment on previous studies on the rhetorical structure of RA abstracts, and will also describe the different categories analysed following Hyland's framework of metadiscourse.

\subsection{THE RHETORICAL STRUCTURE OF THE ABSTRACT}

Regarding the structure of research abstracts, most of the studies have approached their rhetorical patterning in terms of the macro-structure of the research articles across disciplines. In this vein, Swales (1981, 1990) identified a four-part pattern, which corresponded to the overall structure of the research paper, with the moves Introduction-Methods-Results-Discussion, or the so-called IMRD structure. Salager-Meyer $(1990,1992)$ and 
Bhatia (1993) are amongst the authors who have employed these four moves in their research. For his part, Santos (1996), in his study of abstracts in applied linguistics, added an additional move "situating the research", which is normally found at the beginning of the abstract and which was realized by sub-moves which made reference or extended previous research or signalled a problem. Hyland (2000) has also approached the study of abstracts from different disciplines with a five-move model in the line of Santos'study while stating that the abstract is a "high stakes genre where writers must foreground both the main claims of the paper and their importance (Hyland 2000)" (Hyland \& Tse, 2005:126). Lorés (2004) provided a different analytical angle by comparing the rhetorical structure of abstracts to that of the whole research paper or to introductions, drawing on Swales' (1990) Create-a-Research-Space (henceforth, CARS) model. Drawing on her work, the rhetorical skeleton I have devised for the purpose of this paper includes Santos' five moves with a slight variation in the labelling of moves and steps as I have drawn on the terminology from both the IMRD and CARS models. Thus, the following moves have been included (see Figure 1 below): Move 1 Establishing the territory which subsumes steps 1 Claiming Centrality, step 2 Making generalizations, and step 3 Literature Review; then I have incorporated Move 2 Signalling a gap which is enacted through steps 1 Counterclaiming and/or step 2 Gap signalling. For its part, Move 3 presents the research and purpose, Move 4 deals with the methodology or procedure followed, Move 5 introduces the findings and Move 6, which has been labelled discussion, incorporates an explicit assessment of the relevance and/ or contribution of the findings and/or points to further avenues of research.

MOVES

Move 1: Establishing the territory

Move 2: Signalling a gap

Move 3: Indicating purpose

Move 4: Methodology

Move 5: Results

Move 6: Discussion

Figure 1: The rhetorical structure of abstracts in the field of Food Science \& Technology

\subsection{HYLAND'S CATEGORISATION OF INTERPERSONAL METADISCOURSE}

Metadiscourse is an important rhetorical, subjective and culture bound means for the production of any type of discourse (cf. Hyland 1996a, 1998). Recent models of metadiscourse, especially Hyland's (2005b), have viewed 
metadiscourse as "self-reflective linguistic expressions referring to the evolving text, to the writer and to the imagined readers of that text" (Hyland 2004:133). Hyland's framework distinguishes between interactive and interpersonal metadiscourse features, with the interactive dimension dealing with "the writer's awareness of a participating audience and the ways he or she seeks to accommodate its probable knowledge, interests, rhetorical expectations and processing abilities" (Hyland 2005b: 49). On the other hand, interpersonal metadiscourse is concerned with the ways the writers comment on their own messages to make their views known, while revealing "the extent to which the writer works to jointly construct the text with the reader" (Hyland 2005b: 49).

Whereas a lot of attention has been devoted to the rhetorical structure of the abstract, fewer studies have addressed the way an interpersonal relationship is built with the audience. As Stotesbury (2003) pointed out, the expression of evaluation, engagement or stance is part of the research abstract. Thus, the interpersonal dimension of the research abstract will be assessed here by looking at stance, drawing on Hyland's framework (2005a).

Stance is enacted through hedging and boosting devices, together with attitudinal markers and self-mentions ${ }^{1}$, as central to the building of a successful argument. Likewise, considering that the corpus is made up of articles written by researchers from two different cultures, some variation might be expected in their use of these metadiscoursal categories and in the way researchers construct the text in a joint effort with their intended audience (Hyland 2005b).

Hedges (likely, perhaps, quite, might) are resources which help weaken the writer's commitment to a proposition, and allow the researcher to present information as opinion, while leavingroom for counterargument (Hyland 1996, 1998). For their part, boosters (obviously, clearly, demonstrate) mark involvement and solidarity with the audience, while attitudinal markers (unfortunately, hopefully, remarkable, appropriate), are more concerned with affective meanings and convey the writer's attitude of surprise, agreement, importance, frustration with regard to the proposition. Self-mentions (we, our, I, me) reveal the degree of explicit authorial presence in the text.

\section{CoRPus OF ANALYSIS}

\subsection{CORPUS COLLECTION PROCEDURE}

A total number of $50 \mathrm{RA}$ abstracts were collected from the field of Food Science and Technology on the basis of the three criteria stated by Nwogu (1997), i.e., representativity, reputation and accessibility. The abstracts

\footnotetext{
1 Hyland's framework also includes engagement markers (reader pronouns, directives, questions, etc.), under the macro-function of engagement. However, these features lie outside the scope of this study.
} 
were obtained from five high-impact internationally refereed journals included in the Journal Citation Reports with ten abstracts per journal, five of which were written by English L1 native researchers (henceforth NSs) and five by English L2 Spanish researchers (henceforth NNSs). The NNSs corpus yielded a total of 4.441 running words, (1.320 distinct words or types and a type/token ration of 41.30). The NSs sub-corpora yielded 5.064 running words (1.535 types and a type/token ratio of 31.90). The articles were electronically retrieved and downloaded and the data collection time included the years 2016-2018. Only papers written by English native speakers with names "native to the country concerned" and whose affiliation was with an institution in countries with English as a first language (Wood, 2001) were selected, and the same criterion was applied to gather the NNSs sub-corpora. The five journals selected belong to the publishing house Elsevier and are: International Journal of Gastronomy and Food Science, Food Bioscience, Journal of Food Engineering, Carbohydrates and International Dairy. The findings obtained here can be said to be extendable to similar abstracts in the field of Food Science and Technology.

\subsection{Data ANALYSIS}

The analysis of the data was carried out in two stages. In the first one and, drawing on the criteria followed by previous researchers (Pho, 2008, Hirano, 2009), I undertook the description of the rhetorical structure of the abstracts by assessing their textual organization with regard to move and/or steps used. I initially assigned each of the sentences to a particular move, although a sentence may sometimes be a realization of more than one move. Thus, I paid attention to linguistic boundaries marking the transition from one move to another, but mainly, my approach was a top-down one, taking content as a main decisive factor together with a bottom-up approach. In order to avoid the subjectivity that my own analysis may bring to the research, a PhD student coded a sample of 16 articles from each of the two sub-corpora drawing on the rhetorical skeleton proposed in 2.1 above. The degree of inter-coder reliability was quite high (more than 90\%).

Next, I calculated the percentage of occurrence of all the moves identified in the 50 abstracts, while also paying attention to possible similarities and/or differences between the two sub-corpora where language could be a key factor. Then, I looked at the pattern sequence of these moves, that is, the most frequent combinations in order to assess their rhetorical complexity. Finally, in order to identify the different interpersonal metadiscoursal categories, I carried out an electronic computer search using the software WordSmith 5.0 and a personal manual reading of the different sections in order to verify that the elements found were used as metadiscourse. The interpersonal categories assessed correspond to Hyland's (2005a) stance markers and include boosters (booster verbs, booster adjectives and authorial presence), hedges (hedging verbs, hedging adjectives, adverbs and noun) 
and attitude markers, which include the interpersonal element of the evaluative that (cf. Hyland and Tse, 2005). Authorial presence, which lies outside the scope of Hyland's stance markers, has been analysed in order to assess the way the authorial voice is constructed in the genre. In addition, other linguistic realizations key in identifying the moves, such as verb tense and voice have also been taken into account whenever relevant for move identification.

\section{RESUlts AND Discussion}

In the following sections I will first report on the findings for the rhetorical structure of the abstracts under analysis, with regard to the moves and steps enacted and their most common pattern sequencing. In a later step I will present the results of the quantitative and qualitative analysis of the different linguistic and metadiscoursal categories evaluated across the different abstract moves.

\subsection{THE RHETORICAL STRUCTURE OF THE ABSTRACT: MOVE AND STEP ANALYSIS}

Table 1 below indicates the frequency of occurrence of the different moves in the 50 abstracts assessed and in each of the sub-corpora. In order to consider that a move is obligatory, a stability threshold was set at 60\% drawing on previous research (Del Saz-Rubio 2019 in press; Kanoksilapatham, 2005). In general terms, it was found that moves 3, 4 and 5 are the obligatory stable ones, as their frequency of appearance is above $60 \%$ and their combination constitutes the basic or minimal core pattern of a certain rhetorical impact, although only move 3 was found to be present in all the abstracts. In contrast, move 1 is enacted with a frequency of $54 \%$ (in 27 of the abstracts assessed), while move 6 is used in $42 \% \%$ of the abstracts ( 21 abstracts deploy it), followed by move 2 , enacted in just seven abstracts (14\%). Of special relevance is the fact that moves 1 (38\% vs $16 \%)$ and 2 (10\% v. 4\%), although not obligatory, are employed twice as much by the NSs than by the NNSs, whereas the core moves 3-4-5 and the optional move 6 are enacted with a similar percentage of frequency in the two sub-corpora:

\begin{tabular}{|c|c|c|c|c|c|c|}
\hline $\begin{array}{c}\text { Abstract } \\
\text { Moves }\end{array}$ & $\begin{array}{c}\mathbf{N}^{\circ} \text { of arti- } \\
\text { cles }\end{array}$ & $\%$ & $\begin{array}{c}\mathbf{N}^{\circ} \text { of articles NSs } \\
\text { group }\end{array}$ & $\%$ & $\begin{array}{c}\mathbf{N}^{\circ} \text { of articles } \\
\text { NNSs group }\end{array}$ & $\%$ \\
\hline M1 & 27 & $54 \%$ & 19 & $38 \%$ & 8 & $16 \%$ \\
\hline M2 & 7 & $14 \%$ & 5 & $10 \%$ & 2 & $4 \%$ \\
\hline$M 3$ & 50 & $100 \%$ & 25 & $50 \%$ & 25 & $50 \%$ \\
\hline$M 4$ & 44 & $88 \%$ & 23 & $46 \%$ & 22 & $44 \%$ \\
\hline
\end{tabular}




\begin{tabular}{|c|c|c|c|c|c|c|}
\hline M5 & 48 & $96 \%$ & 25 & $50 \%$ & 23 & $46 \%$ \\
\hline M6 & 21 & $42 \%$ & 10 & $20 \%$ & 11 & $22 \%$ \\
\hline $\begin{array}{c}\text { Total of abs- } \\
\text { tracts }\end{array}$ & 50 & $100 \%$ & 25 & $50 \%$ & 25 & $50 \%$ \\
\hline
\end{tabular}

Table 1: Frequency of occurrence per move and corpora

M1 Establishing the territory; M2 Signalling a gap; M3 Indicating Purpose; M4 Indicating method or procedure; M5 Presenting findings; M6 Discussing findings. NSs= native speakers; NNSs=non-native speakers.

Move 1 is primarily enacted through step 2 making generalizations (48\% of the cases), as it is through this step that the research at hand is situated within the broader research domain. Sometimes references to previous literature are made $(8 \%)$, especially when step 2 is also deployed, and only 4 of the abstracts $(8 \%)$ make use of step 1 in order to claim centrality with regard to the research topic under investigation. Move 2 is mainly enacted through a combination of counterarguments (4\%) with the help of discourse markers of contrast, and with the signalling of a gap or caveat in the literature $(12 \%)$.

With regard to the different move combinations or patterns deployed, findings indicate that out of the 50 abstracts analysed, 54\% (a total of 27 abstracts) deploy the moves traditionally associated with the IRMD and CARS structure, that is, core moves $3,4,5$ and 6 , in combination with moves 1 and 2. These would account for the most complex abstracts from a rhetorical point of view. In contrast, 23 of the abstracts assessed which represent $46 \%$ of the total, exclusively follow the IMRD structure and hence, do not include either contextualization of the topic of research being carried out or the signalling of a gap, problem or niche to be filled in.

If we consider the L 1 of the researchers, it should be noted that out of the 27 abstracts that make up the most complex set, 19 have been authored by the NSs group (70.4\%) compared to only $8(29.6 \%)$ authored by NNSs. In contrast, out of the 23 abstracts which are less rhetorically complex, 17 $(34 \%)$ have been authored by NNSs versus six $(12 \%)$ which belong to the NSs group. These findings seem to point to a tendency in the group of NNSs to write less complex rhetorical abstracts, while the opposite seems to be true for the NSs group, as researchers in this group seemed to deploy a higher number of moves in their production of abstracts. This finding is in line with Martín-Martín's study (2005) in which he observed that the English abstracts were more complete than the Spanish ones with regard to their use of the main structural moves. Although it cannot be concluded that the abstracts authored by NNSs are deficient, it is true that, as research on cognitive psychology has shown, the textual comprehension of a text decreases if it has a deficient rhetorical structure (Carrell, 1984; Carrell et al., 1989; Salager-Meyer, 1991). These findings cannot be deemed to be journal sensitive considering that the abstracts which comply with the IMRD structure 
span across different journals and do not seem to follow a pattern in the different groups analysed.

Table 2 below illustrates the most commonly identified patterns regarding the combination of the different moves used for analysis and their frequencies of occurrence:

\begin{tabular}{|c|c|c|}
\hline & $\mathrm{N}^{\circ}$ of abstracts & $\%$ \\
\hline $\begin{array}{c}\text { Articles following the combinatory IMRD+CARS } \\
\text { structure }\end{array}$ & & \\
\hline M1+M2+M3+M4+M5+M6 & 3 & $6 \%$ \\
\hline M1+M2+M3+M4+M5 & 3 & $6 \%$ \\
\hline M1+M2+M3+M5+M6 & 1 & $2 \%$ \\
\hline M1+M3+M4+M5+M6 & $\mathbf{5}$ & $\mathbf{1 0} \%$ \\
\hline M1+M3+M4+M5 & $\mathbf{1 1}$ & $2 \%$ \\
\hline M1+M3+M5+M6 & 1 & $2 \%$ \\
\hline M1+M3+M5 & 1 & $2 \%$ \\
\hline M1+M3+M4 & 1 & $2 \%$ \\
\hline M1+M2+M5 & 1 & $54 \%$ \\
\hline Total & 27 & $\mathbf{2 2 \%}$ \\
\hline Articles following the IRMD structure & $\mathbf{2 1}$ & $\mathbf{2 2 \%}$ \\
\hline M3+M4+M5+M6 & $\mathbf{1 1}$ & $2 \%$ \\
\hline M3+M4+M5 & 1 & $46 \%$ \\
\hline M3+M5 & 23 & \\
\hline Total & & \\
\hline
\end{tabular}

M1 Establishing the territory; M2 Signalling a gap; M3 Indicating Purpose; M4 Indicating method or procedure; M5 Presenting findings; M6 Discussing findings.

Table 2: Rhetorical structure of abstracts in Food Science \& Technology

The core move pattern is made up of moves 3, 4 and 5, as indicated above. All the abstracts deploy move 3 and they consequently present the purpose of the research, whereas move 4 , describing the methodology or procedure is deployed in 45 of the abstracts assessed (with the exception of 5 abstracts, 2 in the NSs group and 3 in the NNSs one). Bhatia (1993:2) maintained that the discussion of methodology and experimental procedures was "crucial in research abstracts" and this is in line with the findings here. Move 5, presenting results, is also a key move, present in all the abstracts except for one in the NSs group, which does not include any finding, whereas the discussion of the findings, or move 6 , is less pervasively employed as not all the abstracts seem to comment on the usefulness, applications or limitations of the findings. 14 abstracts authored by NNSs give low priority to move 6 , whereas 16 abstracts written by NSs also omit this move. In this vein, the most pervasive move combinations are $M 1+M 3+M 4+M 5(22 \%)$, which complies with the IMRD and CARS structure, and the patterns $M 3+M 4+M 5+M 6(22 \%)$ and $M 3+M 4+M 5(22 \%)$, which comply with the IMRD structure. These two combinations are followed by the fourth and fifth most pervasive patterns which include moves 1 and 2, and move 6 as either obligatory or optional: $M 1+M 2+M 3+M 4+M 5+(M 6)(6 \%)$. 


\subsection{LINGUISTIC REALIZATIONS AND INTERACTIONAL MARKERS ACROSS MOVES}

\subsubsection{GenERAL FINDING}

General findings point to 278 counts of metadiscoursal units employed in the 50 abstracts assessed. In other words, the interpersonal features analysed occur with a normalized frequency of 29.2 per 1000 words $^{2}$. The interpersonal features tend to cluster in certain moves, more specifically, move 5 agglutinates, by far, the majority of the metadiscoursal features with a total of 155 raw counts which represent $56 \%$ of the total (16.3 per 1000 words). This move is followed by move $1(16 \%)$, move $6(14 \%)$ and move 3 $(10 \%)$. If we compare the two sub-corpora, the abstracts authored by NSs agglutinate $59 \%$ (17.1 per 1000 words) of the metadiscourse features, while in the NNSs group, interpersonal features represent $41 \%$ of all the units (12.1 per 1000 words) (see Table 3 below). Thus, it can be concluded that the abstracts authored by native speakers tend to include slightly more metadiscoursal elements:

\begin{tabular}{|c|c|c|c|c|c|c|c|}
\hline Moves & Counts & $\%$ & $\begin{array}{c}\text { Normalized F. } \\
\mathbf{1 0 0 0} \text { wds }\end{array}$ & $\begin{array}{c}\text { NSs } \\
\text { group }\end{array}$ & $\%$ & $\begin{array}{c}\text { NNSs } \\
\text { group }\end{array}$ & $\%$ \\
\hline M1 & 45 & $16 \%$ & 4.7 & 29 & $11 \%$ & 15 & $5 \%$ \\
\hline M2 & 6 & $2 \%$ & 0.6 & 2 & $1 \%$ & 4 & $1 \%$ \\
\hline M3 & 29 & $10 \%$ & 3.1 & 18 & $7 \%$ & 11 & $4 \%$ \\
\hline M4 & 5 & $2 \%$ & 0.5 & 2 & $1 \%$ & 3 & $1 \%$ \\
\hline M5 & 155 & $\mathbf{5 6 \%}$ & 16.3 & 99 & $36 \%$ & 57 & $21 \%$ \\
\hline M6 & 38 & $14 \%$ & 4.0 & 13 & $5 \%$ & 25 & $9 \%$ \\
\hline Total & 278 & $100 \%$ & 29.2 & 163 & $59 \%$ & 115 & $41 \%$ \\
\hline
\end{tabular}

M1 Establishing the territory; M2 Signalling a gap; M3 Indicating Purpose; M4 Indicating method or procedure; M5 Presenting findings; M6 Discussing findings. NSs= native speakers; NNSs=non-native speakers.

Table 3: Distribution of Interpersonal features across moves

Regarding the overall use of the different interpersonal categories assessed, there is a balanced presence between attitude markers, which incorporates the evaluative that expression, (31\%, 8.94 per 1000 words) and hedging devices (35\%, 10.31 per 1000 words), followed by boosters $(28 \%$, 8.31 per 1000 words) and a less pervasive category of authorial presence $(6 \%, 1.8$ per 1000 words). Table 4 below shows the distribution of the different categories in the two sub-corpora and their normalized frequencies. Even if the frequency of hedging devices seems to be balanced, not only in general, but also in both of the corpora, the use of booster devices is markedly higher in the NSs group than in the NNSs one (10.47 versus 5.85 words per 1000 words, respectively) with the English researchers using more

\footnotetext{
${ }^{2}$ I have incorporated normalized frequencies as two corpora are being compared, whereas the percentages provide an overall view of the frequency of moves.
} 
booster adjectives than the Spanish ones. Less remarkable is the difference these two groups show regarding their use of attitude markers (8.10 versus $6.76)$ and with regard to the that evaluation feature (1.78 vs 1.13 ) or authorial presence:

\begin{tabular}{|c|c|c|c|c|c|c|c|}
\hline $\begin{array}{c}\text { Metadiscourse } \\
\text { categories }\end{array}$ & $\begin{array}{c}\text { NNs } \\
\text { corpus }\end{array}$ & $\begin{array}{c}\text { Freq. } \\
\mathbf{1 0 0 0} \\
\text { wds }\end{array}$ & NSs corpus & $\begin{array}{c}\text { Freq. } \\
\mathbf{1 0 0 0} \\
\text { wds }\end{array}$ & Total & $\begin{array}{c}\text { Freq. } \\
\mathbf{1 0 0 0} \\
\text { wds }\end{array}$ & $\begin{array}{c}\text { \% of } \\
\text { fre- } \\
\text { quency }\end{array}$ \\
\hline Epistemic verbs & 24 & 5.40 & 27 & 5.33 & 51 & 5.37 & $18 \%$ \\
\hline Hedging verbs & 5 & 1.13 & 9 & 1.78 & 14 & 1.47 & $5 \%$ \\
\hline Hedging adj/adv & 17 & 3.83 & 16 & 3.16 & 33 & 3.47 & $12 \%$ \\
\hline Total Hedges & $\mathbf{4 6}$ & $\mathbf{1 0 . 3 6}$ & $\mathbf{5 2}$ & $\mathbf{1 0 . 2 7}$ & $\mathbf{9 8}$ & $\mathbf{1 0 . 3 1}$ & $\mathbf{3 5 \%}$ \\
\hline Booster adjectives & 6 & 1.35 & 21 & 4.15 & 26 & 2.74 & $9 \%$ \\
\hline Booster verbs & 20 & 4.50 & 32 & 6.32 & 52 & 5.47 & $19 \%$ \\
\hline Total Boosters & $\mathbf{2 6}$ & $\mathbf{5 . 8 5}$ & $\mathbf{5 3}$ & $\mathbf{1 0 . 4 7}$ & $\mathbf{7 9}$ & $\mathbf{8 . 3 1}$ & $\mathbf{2 8 \%}$ \\
\hline Attitude markers & $\mathbf{3 0}$ & $\mathbf{6 . 7 6}$ & $\mathbf{4 1}$ & $\mathbf{8 . 1 0}$ & $\mathbf{7 1}$ & $\mathbf{7 . 4 7}$ & $\mathbf{2 6 \%}$ \\
\hline That evaluation & $\mathbf{5}$ & $\mathbf{1 . 1 3}$ & $\mathbf{9}$ & $\mathbf{1 . 7 8}$ & $\mathbf{1 4}$ & $\mathbf{1 . 4 7}$ & $\mathbf{5 \%}$ \\
\hline Personal Involvement & 8 & 1.80 & 9 & 1.78 & 17 & 1.79 & $6 \%$ \\
\hline Total features & $\mathbf{1 1 5}$ & 25.90 & $\mathbf{1 6 3}$ & 32.19 & $\mathbf{2 7 8}$ & 29.25 & $100 \%$ \\
\hline
\end{tabular}

Table 4: Raw and Normalized Frequencies of Metadiscoursal Categories

For its part, Table 5 below illustrates the distribution of metadiscoursal units across moves:

\begin{tabular}{|c|c|c|c|c|}
\hline $\begin{array}{c}\text { Abstract } \\
\text { moves }\end{array}$ & \% Booster use & $\begin{array}{c}\text { \% Attitude } \\
\text { marker }\end{array}$ & \% of Hedge use & $\begin{array}{c}\text { \% of Authorial } \\
\text { presence }\end{array}$ \\
\hline M1 & $7 \%$ & $15 \%$ & $26 \%$ & $18 \%$ \\
\hline M2 & $3 \%$ & $1 \%$ & $2 \%$ & $6 \%$ \\
\hline M3 & $12 \%$ & $13 \%$ & $2 \%$ & $53 \%$ \\
\hline M4 & $2 \%$ & $1 \%$ & $1 \%$ & $12 \%$ \\
\hline M5 & $68 \%$ & $48 \%$ & $56 \%$ & $12 \%$ \\
\hline M6 & $8 \%$ & $21 \%$ & $13 \%$ & $0 \%$ \\
\hline
\end{tabular}

Table 5: Percentage of occurrence of metadiscourse features across moves

\subsubsection{THE DISTRIBUTION OF INTERACTIONAL MARKERS ACROSS ABSTRACT MOVES}

In what follows, a quantitative and qualitative description of each of the moves identified and of the features most commonly enacted in each of them is provided:

\section{a) Move 1: Establishing the territory}

With this move, researchers situate the piece of research by positioning it relative to already existing frames of knowledge or by focusing on the relevance of the topic under study. This move is normally enacted through the step making generalizations, which consists of statements which help provide a context or framework for the research carried out. The verb tense employed to realize this step is mostly the present simple (38 articles) and the most pervasive voice is the passive. With regard to the deployment of 
metadiscourse features, this move mainly resorts to the use of hedges $(26 \%)$ to tune down the force of the propositional content conveyed in order to avoid sounding too categorical. Through the use of attitude markers $(15 \%)$ and self-mentions, (18\%), authors also express their assertiveness and affective attitude towards the ideational content transmitted.

Within hedges, epistemic verbs such as can, may and the semi-auxiliary appear are quite pervasive, together with epistemic adverbs such as just, only, or normally. In example 1 below, the researchers prepare the ground by reminding or informing the reader of the fact that milk fat globule membrane, which constitutes the object of investigation, is a source of food-derived glycans, which can prevent Escheriachia coli O157:H7 and which are also likely to decrease the need for antibiotics. Thus, they somehow contextualize the topic of investigation and prepare the ground for their piece of research. However, such statements are tuned down and made tentative through the use of these devices:

(1) The bovine milk fat globule membrane (MFGM) is a source of food-derived glycans that can offer an approach to prevent Escherichia coli O157:H7 infection by inhibiting attachment of the pathogen to host cells. Such glycans may decrease the need for antibiotic treatment by acting as prophylactics. In this study, we generated a defatted bovine MFGM fraction, rich in proteins and glycoproteins, and demonstrated its ability to prevent the association of several enterohaemorrhagic E. coli O157:H7 strains with human colonic adenocarcinoma, HT-29 cells. (JofIntDairy_05_Eng)

On other occasions, the authors express their attitude towards some aspects through attitudinal adjectives such as broad, critical, desirable, or important. In example 2 below, the researchers convey the importance of addressing the obesity epidemic by modifying the energy content of foods. By using the adjective important or qualifying the role of food handlers as uniquely placed to influence the provision of reduced-calorie foods, they are somehow positioning themselves with regards to the topic under analysis as committed to its study:

(2) Modifying the energy content of foods, particularly foods eaten away from home, is important in addressing the obesity epidemic. Food handlers in the restaurant industry are uniquely placed to influence the provision of reduced-calorie foods, but little is known about their opinions on this issue. (JofGast_03_Sp)

In examples (3) and (4) below, topic generalizations are conveyed as examples of a trend (the consumption of gluten free foods, or entomophagy) and progressive tenses are employed to emphasize this aspect. The use of comparative structures also helps to convey the idea that the current situation requires further investigation due to its being a pressing issue in the field ${ }^{3}$ :

\footnotetext{
${ }^{3}$ Verb tenses are underlined in the examples provided, while the rest of metadiscoursal features are in italics.
} 
(3) The consumption of gluten free foods is increasing in today's society and consumers are demanding more from their gluten free products. Consumers are also looking for local alternatives to conventionally produced foods. This study compares the sensory aspects of industrially processed gluten free bread and locally produced, artisanal gluten free bread. (JofGast_02_Eng)

(4) Due to the increasing demands on the global food supply, entomophagy is being strongly considered as a viable alternative to protein derived from traditional animal sources. (JofGast_01_Eng)

Regarding verb tenses, the majority of the abstracts use present perfect tenses to claim centrality (step 1), whereas topic generalizations (step 2) are conveyed with the use of present simple tenses either in the active or in the passive voice, followed by the use of present simple continuous in some examples. If we compare the use of metadiscoursal features in the NSs and NNSs groups, hedges are used with a frequency of 6.1 per 1000 words by the native researchers, whereas the Spanish ones employed them with a frequency of 5.4 per 1000 words. Boosters are employed with a markedly higher frequency by the NSs (8.1 versus 3.4 per 1000 words), whereas the frequency of attitude markers is quite similar in both sub-corpora (3.4 versus 5.1 for the NNSs and NSs, respectively).

\section{b) Move 2: Gap Signalling}

This non-obligatory move is not pervasively employed. When used, this move tends to be deployed by an explicit counterargument, signalled by the use of contrast linking words such as although or but, as in examples 5 and 6 below, to indicate that a caveat exists in the body of knowledge. This gap is also signalled thanks to the lexis employed, for example verbs such as suffer from, drawbacks, remain, or challenge, or sentences such as we do not know the crystallization conditions, which point to the existence of a lacuna that should be filled in. The verb tenses most commonly enacted to realize this move are present simple either in the active or passive voice:

(5) Although cellulosic fibers are increasingly used in textile products, current methods for production of cellulose-based textiles suffer certain economic and/or environmental drawbacks. (Carbohydrate_02_Eng)

(6) Moisture diffusion in lipids has been traditionally described by generic models that do not offer complete information about its structural dependency. Due to the lack of a predictive structure-based model in literature, we do not know the crystallization conditions needed to favorably alter structure and decrease moisture transport in lipids. (Journal of Food Engineering_01_Eng)

\section{c) Move 3: Stating the purpose}

This move is present in all the abstracts, which, for promotional purposes, clearly present their aims, or state what their research adds to already existing studies or how it solves an existing deficiency in the field. The 
purpose of the research is normally realised with the past simple, either in the active or in the passive voice, followed by the present simple tense. With regard to the grammatical subjects employed, and in line with Pho's findings (2008), when the researchers use subjects that make reference to their own work, i.e., "this study" or "this paper", the verb tense employed tends to be the present simple ("this paper describes", "this study reports", or "in this work, we report"), to emphasize the immediacy and/or the physicality of the research, although two examples have been found in which this study is followed by verbs in the past simple tense. In contrast, when the grammatical subjects refer to more specific aspects of the research (objectives, aims, etc.,) the preferred option is the past simple tense: "the objectives of the present study were", "the objective of this study was", or "the aim of this work was"). Authorial presence in the form of pronouns (we, our approach), has also been found in this move although its use is quite limited:

(7) The objectives of the present study were to determine the general public and food handlers' knowledge and opinions, issues and barriers related to providing these items on the menu, and about the influence of the calorie content of restaurant items on customer intake. (JofGast_03_Sp)

(8) In this study, we generated a defatted bovine MFGM fraction, rich in proteins and glycoproteins, and demonstrated its ability to prevent the association of several enterohaemorrhagic E. coli O157:H7 strains with human colonic adenocarcinoma, HT-29 cells. (JofIntDairy_05_Eng)

With regard to the use of interactional markers, it should be noted that the research purposes are quite objectively transmitted although sometimes researchers employ boosters, in order to convey their commitment to the purpose of the research, and attitude markers, which as Hyland indicated (2004:76) have the function of promotion in the move that situates the research. In example 9 above the booster verb demonstrate helps convey the researchers' commitment aided by the authorial presence through the plural personal pronoun.

In some of the abstracts analysed, move 3 is coalesced with move 4 within the same sentence (cf. Santos 1996 for similar insights), as in example 10 below, where the purpose was to obtain different levels of casein modification through the procedure of succynylation:

(9) Plasmin-induced hydrolysis of casein in milk can lead to many defects including proteolysis, age gelation, and bitterness. The susceptibility of casein to plasmin can be affected by micellar structure and modification of the lysine residues on Caseins. Different levels of casein modification and dissociation of the casein micelle structure were achieved through succinylation. (JofIntDairy4_Eng)

\section{d) Move 4: Methodology or procedure}

Move 4 is the most objective one in terms of its deployment of stance markers considering that these categories feature at their lowest here. The 
most common verb tense is past simple used in the passive followed by the past simple tense. This was an expected finding considering that the methodology and procedures have already been applied and, hence, researchers are just reporting what they did rather than who did it. This finding coincides with Anderson and McLean's research (1997) and Santos' (1996), who identified the past passive verb as one of the key linguistic features realizing the methods move in medical abstracts. This objectivity and impersonality is reinforced by the lack of other interpersonal categories, and by the large number of passive structures employed in comparison with the other moves (cf. Santos, 1996 for similar findings):

(10) This paper analyses consumers' preferences for cheese packaging. The methodology used is a two-step approach. Firstly, focus groups were developed to identify the most relevant attributes and levels when choosing a cheese package. Secondly, a choice experiment was applied to analyse the influence of those attributes on consumers' buying decisions. (IntDairy03_Sp)

(11) Goethite nanoparticles (NPs) and their cellulose composites were prepared with good yield $\sim 97 \%$, and characterized by thermal gravimetric analysis (TGA), Fourier transform infrared (FTIR) spectroscopy, Raman spectroscopy, nitrogen gas adsorption/desorption (BET), powder X-ray diffraction (pXRD) and transmission electron microscopy (TEM). (Carbohydr_03_Eng)

\section{e) Move 5: Presenting findings}

This is a highly rhetorical move where researchers present their findings and make claims of new knowledge through a balanced combination of boosters $(68 \%)$, hedges (56\%) and attitude markers (48\%). Not in vain, other studies have found that evaluation tends to cluster in the reporting of findings and concluding sections of abstracts (cf. Stotesbury, 2003, Gillaerts and Van de Velde, 2010) as it is where more controversial claims are presented in comparison with the rest of the abstract sections. Thus, more negotiation is required between researchers and their audience in order to accommodate alternative voices, while still presenting the novelty of the researchers' findings. In this vein, hedges, on the one hand, and boosters and attitude markers, on the other, are aspects of the same coin as their joint deployment allows researchers to mitigate or tune down their scientific claims, to convey their degree of commitment towards the proposition and their affective meanings and, hence, create an authorial voice. For example, in 12 below, researchers use hedging verbs such as suggest, show and propose, in order to lessen their commitment to the findings and allow room for disagreement; however, they also convey their attitude towards the findings by using the attitude adjective critical, which certainly commits them to the propositional finding, or the adverb significantly which reflects their affective opinion. In example 13 below, hedging devices such as mainly or presumably are employed to tentatively account for the findings, but where commitment is also conveyed with the help of boosters such as show coupled with excellent: 
(12) The data suggested that the critical water activity (aw) of the three types of potato chips ranged from 0.70 to 0.85 . At higher aw (above 0.85), RPC displayed the highest moisture absorption capacity, followed by FPC, and BCPC. The results also showed that a higher percentage of porosity is followed by higher moisture content in the potato chips. The findings propose that water vapor sorption of the three types of potato chip was governed by the Flory-Huggins model. In addition, the oil significantly blocked water sorption in the samples ( $\mathrm{p}<$ 0.05). (JofFoodEng_02_Eng)

(13) After hydrolysis, more than $73 \%$ of protein was recovered in soluble form, whereas $11-$ $15 \%$ was insoluble. Carotenoids, determined as astaxanthin, were mainly present $(497 \%)$ in the insoluble protein fraction, presumably in form of complexes of high molecular weight. Protein hydrolysates showed excellent solubility (497\%) in a wide $\mathrm{pH}$ range (3-10), good oil holding capacity (0.86-1.83 g oil/g hydrolysates) and discrete inter-facial properties. Besides, all shrimp hydrolysates at concentration of $1 \mathrm{mg} / \mathrm{mL}$ provided DPP-IV inhibition activity (22.7-61.7\%) and those prepared with trypsin and Alcalases also inhibited PO (3540\% inhibition). (FoodBio_03_Sp)

Regarding the L1 of the authors, the NSs group employ boosters with a higher normalized frequency, 8.1 versus 3.8 for the NNSs group. This is a significant difference which points to a poorer use of booster verbs, considering that English researchers used twice as many boosting verbs (confirm, demonstrate, determine, show, find, reveal, etc.,) compared to the Spanish ones (show, confirm, prove).

\section{f) Move 6: Reporting the findings and conclusions}

Move 6 incorporates an explicit assessment of the relevance and/or contribution of the findings obtained and sometimes points to further avenues of research. However, and in spite of the persuasive value of this move, it has not been found to be an obligatory one. Present simple tenses, either in the active or passive are the most pervasive tenses employed together with modal epistemic verbs such as may or could, or would, all of them verbs which help to tentatively convey the possible potential applications of the findings obtained. Attitude markers represent $21 \%$ of the features identified and hedges display a frequency of use of $13 \%$. The use of attitudinal lexis is expected considering that researchers evaluate and/or contextualize the validity, applicability or usefulness of the findings. It has been observed that it is quite common to find a combination of hedges and attitude markers, with hedges modifying or mitigating attitude markers or boosters, as in example 14 below, where the use of the epistemic verb appears to seems to detach the researcher from the finding while also mitigating the force of the attitude marker interesting, which reveals the researcher's personal opinion:

(14) Modification of gelatin-based foams and gels with the addition of TGase appears as an interesting approach for culinary recipes in which gelatin should be heated. However, a careful optimization should be done to avoid a too rubbery texture. (JofGast_02_Sp) 
In example 15 below, researchers indicate that their results offer evidence which is compelling, hence, conveying their own affective meaning, but the commitment to this statement is mitigated by the that clause which follows in which they tentatively indicate that the DSC can be used for the identification of syrup to honey, hence allowing room for disagreement. What is more, they keep on mitigating their findings by acknowledging what is still to be done for their findings to be conclusive. In 16 the use of may as a hedging device helps mitigate the author's view conveyed by the attitude marker beneficial:

(15) These results offer compelling evidence that the DSC can be used for the identification of addition of syrup to honey, although to be conclusive a greater number of honey types must be considered. (JofFoodEng_01_Sp)

(16) MLH could significantly alleviate fatigue of the mice and had an anti-oxidative effect on aging mice. Conclusively, monkfish liver hydrolysates may be a beneficial ingredient to use in functional foods, indicating that monkfish liver is valuable for further study. (FoodBio_01_Eng)

Regarding the L1 of the authors, the NSs group has used less stance features in move 6 than the NNSs group, which is a remarkable fact. In fact, the interactional markers amount to a total of $22 \%$ for the group of the Spanish researchers, whereas in the native speakers group, they represent $8 \%$ of all the features assessed, although the move is deployed with a similar frequency in both sub-corpora $(22 \%$ and $20 \%$, respectively for NNSs and NSs). Hedges are employed with a frequency of 2.3 words per 1000 (22\%), by the NNSs group versus $0.6(6 \%)$ in the sub-corpora authored by the NSs, thus pointing to a significant difference between both groups. The other categories are employed with a similar frequency: attitude markers are used slightly more by NNSs (2.5 versus 1.4 per 1000 words by NSs).

\section{CONCLUDING REMARKS}

Based on the premise that each academic discipline may exert an influence over the rhetorical structure and the linguistic and interpersonal choices of the academic genres which belong to it, in this paper I have carried out a genre-based approach to delineate the rhetorical structure and asses the use of metadiscoursal features in a corpus of 50 research abstracts from the uncharted field of Food Science and Technology.

Findings indicate that only moves 3,4 and 5 are obligatory in the abstracts analysed, and thus, they constitute the core rhetorical pattern most commonly deployed. This is in line with previous research by Pho (2008), who also found that move 6 was not present in all the abstracts in his study. $54 \%$ of the abstracts resort to a combination of the IMRD and CARS model, whereas $46 \%$ of the abstracts deploy moves within the IRMD structure. The abstracts written by the NSs group, seem to be more complete with regard to the use of moves and steps, and hence, more persuasive. In contrast, the 
abstracts authored by the NNSs group tend to include fewer moves, without incorporating moves 1 and 2 from the CARS structure. In other words, the Spanish writers do not seem to resort to gap signalling or counterarguments as a way of presenting their research, despite the persuasive potentiality that such structures have. What is more, even though some of the authors from the native group deploy this move, its frequency use is below $60 \%$ and, hence, it cannot be deemed to be an obligatory move in this discipline (cf. Santos, 1996).

With regard to the use of interpersonal features, the overall results indicate that hedges are used with a higher frequency, followed by boosters and attitude markers and they are not equally distributed over the various moves in line with Pho's research (2008). Hedges, boosters and attitude markers, for instance, are more commonly enacted in moves 5 and 6 as these two sections may contain more controversial claims and, thus, more negotiation is needed between the writer and reader together with the need to accommodate alternative voices than, for example, in the methodology section, which has been shown to be quite an objective move. Hyland's classification of stance markers or interactional metadiscourse features has proved to be a good working model to empirically assess the way researchers craft their relation to their intended audiences. Results show that in spite of the fact that abstracts are condensed genres, attention to the interpersonal relationship between the researcher and the wider scientific community is envisaged. Last, but not least, the findings have pedagogical implications as they point to differences in the ways and frequencies native and non-native researchers deploy certain features, for example, the use of boosters or hedges across moves. This fact was already pointed out by Flowerdew (2001), who highlighted the lack of authorial voice for non-native writers. Further avenues for research should include a broader corpus of analysis, and perhaps a comparison with neighbouring disciplines. Likewise, a closer look at the introduction sections for each of the abstracts should be carried out in order to assess whether the introductions do indeed skip some of the moves, or whether, on the contrary, the research papers whose abstracts are less rhetorically complex also write less convincing or persuasive introductions. In addition, some qualitative research in the form of interviews or questionnaires with the researchers involved, could also be helpful in unveiling the motivations for the choices they have made in the writing of the abstract.

\section{REFERENCES}

ANDERSON, K. \& MACLEAN, J. (1997): "A genre analysis study of 80 medical abstracts", Edinburgh Working Papers in Applied Linguistics, 8, pp. 1-23.

BELLÉS-FORTUÑO, B. \& QUEROL, J. (2010): "Evaluation in research article abstracts: a cross-cutlural study between Spanish and English medical discourse", Lorés Sanz et al., (eds.): Constructing interpersonality: Multiple perspectives and applications to 
written academic discourse, Cambridge. CUP, PP. 83-98.

BHATIA, V. K. (1993): Analysing genre: Language use in professional settings. London: Longman.

BUSÀ M. G. (2005): "The use of Metadiscourse in Abstracts: A comparison between Economics and Psychology Abstracts", Bamford, J. and M. Bondi (eds.), Dialogue within discourse communitites: Metadiscursive perspectives on academic genres, Berlin: Walter de Gruyter, pp. 38-48.

CARRELL, P. L. (1984): "The effect of rhetorical organization on ESL readers", TESOL Quarterly, 18, pp. 441- 469 .

CARRELL, P. L., DEVINE, J. \& ESKEY, D. E. (1989): Interactive approaches to second language reading. Cambridge University Press: CUP.

DEL SAZ-RUBIO, MM. (IN PRESS): "A genre-based approach to the rhetorical structure and use of interpersonal metadiscourse in the Results and Discussion section of Food Science \& Technology Research Articles", Miscelánea: A Journal of English and American Studies.

DORÓ, K. (2013): "The Rhetoric Structure of Research Article Abstracts in English Studies Journal", Prague Journal of English Studies, 2(1), pp. 119-139.

FLOWERDEW, J. (2001): "Attitudes of Journal Editors to Non-native Speaker Contributions", TESOL Quarterly, 35 (1), pp. 121-150.

GILLAERTS, P. \& VAN DE VELDE, F. (2010): "Interactional metadiscourse in research article abstracts", Journal of English for Academic Purposes, 9, pp. 128-139.

HARTLEY, J. (2003): "Improving the Clarity of Journal Abstracts in
Psychology: The case for structure", Science Communication, 24(3), pp. 366-379.

HIRANO, E. (2009): "Research article introductions in English for specific purposes: A comparison between Brazilian Portuguese and English", English for Specific Purposes, 28, pp. 240250.

HU, G. \& CAO, F. (2011): "Hedging and boosting in abstracts of applied linguistics articles: A comparative study of English and Chinese", Medium Journals, 5(3), pp. 234-246.

HUCKIN, T. (2001): "Abstracting from abstracts", Hewings M. (ed.), Academic Writing in Context: Implications and Applications. Papers in honour of Tony DudleyEvans, Birmingham: The University of Birmingham. University Press, 93- 105.

HUNSTON, S. (1993): Evaluation and Ideology in Scientific Writing, Ghadessy, M. (ed.), Register Analysis: Theory and Practice, London and New York. Pinter Publishers, pp. 57-73.

HUNSTON, S. \& THOMPSON, G. (Eds.) (2000): Evaluation in text: Authorial stance and the construction of discourse, Oxford: Oxford University Press.

HYLAND, K. \& TSE. P. (2005): "Hooking the Reader: A Corpus Study of Evaluative That in Abstracts", English for Specific Purposes, 24(2), pp. 123-39.

HYLAND, K. (2000): Disciplinary discourses: Social interactions in academic writing, London: Pearson.

HYLAND, K. (2004): "Patterns of engagement: Dialogic features and L2 student writing", Ravelli L. \& R. Ellis (eds.), Academic writing in context: Social-functional perspectives on theory and practice, London: Continuum, pp. 5-23. 
HYLAND, K. (2005a): "Stance and engagement: A model of interaction in academic discourse", Discourse Studies, 7(2), pp. 173-192.

HYLAND, K. (2005b): Metadiscourse, London: Continuum.

KAFES, H. (2012): "Cultural traces on the rhetorical organization of research article abstracts", International Journal on New Trends in Education and their Implications, 3(2), pp. 207-220.

KANOKSILAPATHAM, B. (2005): "Rhetorical structure of biochemistry research articles", English for Specific Purposes, 24(3), pp. 269-292.

KAPLAN, R. B., CANTOR, S., HAGSTROM, C., KAMHI-STEIN, L., SHIOTANI, Y. \& ZIMMERMAN, C. (1994): "On abstract writing”, Text, 14(3), pp. 401-426.

LORES, R. (2004): “On RA abstracts: From rhetorical structure to thematic organization", English for Specific Purposes, 23, pp. 280-302.

MARTÍN-MARTÍN. P. (2002): "A genre of English and Spanish research paper abstracts in experimental social sciences", English for Specific Purposes, 22/1, pp. 25-43.

MARTÍN-MARTÍN. P. (2005): The Rhetoric of Abstract in English and Spanish Scientific Discourse: A cross-cultural genre-analytic approach, Bern: Peter Lang.

MELANDER, B., SWALES, J.M. \& FREDERICKSON, K.M. (1997): "Journal Abstracts from three academic fields in the United States and Sweden: National or Disciplinary Proclivities?, Duszak, A. (ed.), Intelectual Styles and Cross-cultural Studies Communication, Berlin: Mouton de Gruyter, pp. 251272.
MORENO, A. I. (1997): "Genre constrains across languages: casual metatext in Spanish and English RAs",

NWOGU, K. (1997): "The medical research paper: Structure and functions", English for Specific Purposes, 16(2), pp. 119-138.

PHO, P. D. (2008): "Research article abstracts in applied linguistics and educational technology: A study of linguistic realizations of rhetorical structure and authorial stance", Discourse Studies, 10, pp. 231-250.

SALAGER-MEYER, F. (1990): "Discoursal flaws in medical English abstracts: A genre analysis per research- and text-type", Text, 4, pp. 365-384.

SALGAER-MEYER, F. (1991): "Medical English abstracts: How well are they structured?, Journal of the Association for Information Science and Technology, 42(7), pp. 528-531.

SALAGER-MEYER, F. (1992): "A texttype and move analysis study of verb tense and modality distribution in medical English abstracts", English for Specific Purposes, 11, pp. 93-113.

SAMRAJ, B. (2002): "Introductions in research articles: Variations across disciplines", English for Specific Purposes, 21, pp.1-17.

SAN, L. \& TAN, H. (2012): "A Comparative Study of the Rhetorical Moves in Abstracts of Published Research Articles and Students' Term Papers in the Field of Computer and Communication Systems Engineering", International Journal of Applied Linguistics and English Literature, 1(7), pp. 40-50.

SANTOS, M. B. D. (1996): "The textual organization of research paper abstracts in applied linguistics", Text 16, pp. 481-499. 
STOTESBURY, H. (2003): "Evaluation in research article abstracts in the narrative and hard sciences", Journal of English for Academic Purposes, 2, pp. 327341.

SWALES, J. M. (1990): Genre analysis: English in academic and research settings, Cambridge: Cambridge University Press.

SWALES, J. M. (1981). Aspects of article introductions. Birmingham, England: University of Aston.

TANKÓ, G. (2017): "Literary research article abstracts: an analysis of rhetorical moves and their linguistic realizations", Journal of English for Academic Purposes, 27, pp. 42-55.

WOOD, A. (2001): "International scientific English: The language of research scientists around the world", Flowerdew, J. \& M. Peacock (eds.), Research perspectives on English for academic purposes. Cambridge: Cambridge University Press, pp 7183. 